UDC 811.111'25

DOI https://doi.org/10.26661/2414-1135-2020-80-2-41

\title{
FUNCTIONING OF THE CATEGORY OF MODALITY IN ENGLISH- LANGUAGE DISCOURCE
}

\author{
Stetsyk T. S. \\ Candidate of Philological Science, Associate Professor, \\ Senior Lecturer at the Department of Philology and Translation \\ Ivano-Frankivsk National Technical University of Oil and Gas \\ Karpatska str., 15, Ivano-Frankivsk, Ukraine \\ orcid.org/0000-0002-0707-8746 \\ stetsyktetiana@gmail.com
}

Key words: category of modality, grammatical, logical modality, modality mean, concept, levels of linguistic structure, lexical mean, modal verbs to have/must.
The category of modality in linguistics is considered to be not fully investigated phenomenon. Not all authors clearly distinguish between two types of modality, namely grammatical and logical ones. There is still no consensus on the question of whether the modality is assigned to the category of modality: whether modality is a category of morphology, syntax or semantics. The concept of modality (from Latin modus - measure, method), which was introduced in relation to the logic of judgment, in fact, yet by Aristotle and which was further developed in the works by I. Kant, further passed into classical philosophical systems, and later found its application in linguistics. The term "modality" is used to define a wide range of phenomena that are heterogeneous in their volume, grammatical properties and degree of decoration at different levels of linguistic structure. The modality sphere includes the following: opposition of statements by the nature of their communicative goal (statement-questionmotivation); opposition with the sign of "statement-negation"; gradation of values in the range of "reality-irreality" (reality-hypothetical realityirreality); different degrees of confidence of the speaker in the reliability of the content of the statement; various modifications of the relationship between the subject and the predicate, expressed by various lexical means ("wishes", "can", "should", necessary"), etc. By modality, we mean the integral system of those aspects of meanings of expression that manifest the speaker's attitude to the following: to the type of connection between the meaningful content of the utterance and the fragment displayed beyond linguistic reality; to the beyond linguistic reality fragment reflected in the statement; to the type of relationship between the subject and the subject of the propositional content of the utterance; to the listener (analyzing the interaction between the speaker and the listener), that is the relationship that emerges in the speaker's desire to influence the listener in an informed aspect. 


\title{
ФУНКЦІОНУВАННЯ КАТЕГОРІЇ МОДАЛЬНОСТІ В АНГЛОМОВНОМУ ДИСКУРСІ
}

\author{
Стецик Т. C. \\ кандидат філологічних наук, доиент, \\ доиент кафедри філології та перекладу \\ Івано-Франківський національний технічний університет нафти і газу \\ вул. Карпатська, 15, Івано-Франківськ, Україна \\ orcid.org/0000-0002-0707-8746 \\ stetsyktetiana@gmail.com
}

\begin{abstract}
Ключові слова: категорія модальності, граматична $i$ логічна модальність, модальне значення, кониепт, рівні лінгвістичної структури, лексичне значення, модальні дієслова to have/must.
\end{abstract}

Категорія модальності в лінгвістиці вважається не дослідженим до кінця явищем. Незважаючи на те, що протягом певного часу модальність залишалась у центрі уваги дослідників, у наш час важко знайти категорію, яка б такою ж мірою характеризувалася відсутністю єдиної думки з приводу іiі походження, структури та характеру значень, які вона передає. Не всі автори чітко розмежовують граматичну та логічну модальність. Немає єдиної думки й у вирішенні питання про рівневу віднесеність категорії модальності: чи $€$ модальність категорією морфології, синтаксису чи семантики. Це, своєю чергою, впливає на визначення взаємозалежності таких категорій, як спосіб, предикативність і модальність. Поняття «модальність» (від лат. Modus міра, метод) введене стосовно логіки судження власне ще Аристотелем i розвинене у працях I. Канта, надалі перейшло у класичні філософські системи, а згодом знайшло своє застосування в мовознавстві. Термін «модальність» використовується для визначення широкого кола явищ, неоднорідних за своїм значенням, граматичними властивостями та ступенем вираження на різних рівнях мовної структури. Сфера модальності включає таке: протиставлення висловлювань за характером їх комунікативної мети (висловлювання-питання-мотивація); протиставлення зі знаком «висловлювання-заперечення»; градація значень у межах «реальністьнереальність» (реальність-гіпотетична реальність-нереальність); різний ступінь впевненості мовця у достовірності змісту висловлювання; різні модифікації відносин між суб'єктом і об' єктом, виражені різними лексичними засобами тощо. Під модальністю розуміють інтегральну систему тих аспектів значення висловлювання, які виражають відношення мовця: до типу зв'язку між смисловим змістом висловлювання та відображеним ним фрагментом понадмовної дійсності; до фрагмента мовної реальності, відображеного у висловлюванні; до типу відносин між підметом та підметом пропозиційного змісту висловлювання; до слухача (аналізуючи взаємодію між мовцем та слухачем), тобто відносин, що виникають у прагненні мовця впливати на слухача в певному аспекті. Особливу ж увагу привертає використання предикативної модальності у політичному дискурсі.
Introduction. Today the problem of modality is one of the most topical issues in linguistics due to its complexity and versatility. Many of its aspects, present in both written and oral speech, still do not have a clear, unambiguous definition, and are actually the subject of discussion $[4 ; 9]$.

The topicality of the study lies in the fact that each statement, message, information, evaluation, incitement, etc. contain different modal nuances, which together make up the modal plane of the sentence. The author is aiming at responding to the following issues: whether modality is a homogeneous universal category inherent in any statement, or there are still different, differentiated types of modality and if so, which exactly and how they are expressed. The object of this scientific research is the application of a field approach to the study of modality in general, its varieties and functioning in the political discourse.

This study is based on the views of such famous linguists as O.I. Beliaeva, O.A. Zvereva, L.S. Yermolaeva, E.V. Gulyga, Ye.I. Shendels, V.V. Vinogradov, V.Z. Panfilov, V.G. Admoni, 
V.G. Gak, S. Balli, Z.M. Baikova, G.A. Zaitseva, I.B. Khlebnikov, G.A. Zolotova, V.N. Bondarenko and many others.

The purpose of the study is to analyze the modality of necessity in English on the basis of English-language political speeches of candidates for the post of the President of the United States (a total of 959 pages). We obtained 497 textual fragments by the method of continuous sampling. The method of quantitative analysis and the comparative method were also applied in order to process language material.

\section{Views on the category of modality}

In modern linguistics there are several views on the category of modality. The key definition is: "The relation of the message contained in the sentence to reality is a modal relation" [1, p. 84]. This definition characterizes modality in terms of content, though modality also acts as a "unit of the expression", emphasizing the syntactic means of its expression: "Forms of grammatical expression of various relations of language content to reality constitute the syntactic unity of modality" [5, p. 72]. However, the definition of modality as a semantic category is specified by introducing a speaker. Then modality expresses "the relation of utterance to reality which is established by the speaker" [5, p. 75]. Such maxims form an opinion regarding the impossibility of simultaneous definition of modality as a category expressing "the relation of utterance to reality", viewing the reality as the objective world, and at the same time arguing that this relation is established by the speaker, namely, it is the evaluative attitude of the speaker to the reported fact, representing his subjective opinion (R.S. Pospelov, P.S. Kuznetsov, S.D. Nikiforov). Scholars try to overcome contradictions by excluding the speaker (subject) from the definition, making this definition "more objective" [10, p. 108]. O.O. Kholodovych notes, "The category of modality expresses the relation of action to the reality, a different degree of reality of the action itself, regardless of the speaker' relation to it. The presence or absence of action, possibility, necessity of action, desire, aspiration for its realization etc. - all these meanings are transmitted by the category of modality" [12, p. 104].

Summing up various positions, we can state that modality is a conceptual category with the meaning of the speaker's relation to the content of the utterance and the relation of the content of the utterance to reality (relation of the message to its practical implementation), expressed by grammatical and lexical-grammatical means, such as form of manner, modal verbs, intonation, etc. Modality is characterized both as a content unit and as an expression unit. Thus, "modality is a semantic category, a type of meaning or a set of meanings that have different reflections in language" [11, p. 357]. Despite all the variety of means of expressing modality, "the essence of modal meanings leads to the fact that in language they are realized mainly in the predicate, which follows from the very logical nature of modality, which states the nature and content of the subject's relation to the predicate of evaluation" $[6, p .110]$. It is fundamentally important to take into account I.B. Khlebnikov's idea: "The study of modal meanings should begin with the analysis of the possibility of expressing modality in the grammatical categories of the verb or its lexical meaning" [11, p. 358]. Such thoughts allow us to conclude that no matter what form of expression this or that communicative modality has, the only adequate way to present its communicative essence is the paraphrase in terms of a verb with the meaning of communicative modality of reality, possibility, necessity, etc.

\section{Expression of modality in English}

Modality is defined as a linguistic category that expresses the speaker's evaluation of the reality in terms of the way in which the connection between the subject and its feature exists, relying as well on the degree of speaker's awareness of this connection. This category is closely related to the communicative intention of the speaker and is realized in the process of communication in the form of different communicative-syntactic and modal types of utterances in different linguistic acts.

In the well-known classification by J. Sern there are five basic types of linguistic (illocutionary) acts: representatives, directives, commissions, expressives and declarations [2, p. 66].

Among the means of expressing directive language acts in English, there are four groups:

1. Performative words, for example, order, suggest, advise, beg, tell;

2. Grammatical forms of the imperative mood;

3. Means that acquire the illocutionary character of the directive due to the convention of use ("language clichés"):

- interrogative and non-interrogative statements with modal verbs;

- narrative sentences with verbs in the indicative mood;

- exclamations, noun, adverb one-member sentences;

- phraseologized expressions with imperative semantics, for example, will you be so kind, do you mind, you'd better.

4. Unconventional means, the illocutionary characteristic of which is realized in a specific context.

Each type of directive language act corresponds to certain structural variants, language variants of which depend on the specific communicative conditions. Structural variants of expressing advice in English include the following forms:

a) performative verbs advise, recommend;

b) syntactic construction you'd better; 
c) modal words can, could, should, ought to in combination with the infinitive;

d) modal verbs might in interrogative constructions;

e) complex conditional sentence with forms of subjunctive mood;

f) general interrogative and indirect interrogative sentences [2, p. 66-67].

"Optative modal constructions are used in various combinations in expressive language acts of wishes, curses. Each of these linguistic acts corresponds to special ways of expressing different degrees of conventionality. Thus, in English, a wish can be explicitly expressed using a two-member construction with the verb wish and a direct object, which includes information about the nature of the wish. The wish can also be transmitted trough:

1. Conventional language forms - syntactic model "May + infinitive" and imperative.

2. One-member clichéd sentences with a noun, a modified adjective or a quantitative attribute" [3, p. 67].

"The proper meaning of desirability has many shades of meaning associated with the implementation or non-implementation of the desired action and is realized through three modal types of expressions I wish + subjunctive, If only + subjunctive, Let + it / there / this + Infinitive" [2, p. 68].

"Modal types of sentences, whose predicates include a modal verb, participate in the realization of three types of linguistic acts:

1. Representative-ascertaining, reflecting objective relations of the possibility or coercion of the connection between the object and the characteristics in the system of external and internal factors.

2. Representative-suggestive and deductive, expressing the epistemic possibility or necessity of the connection between the object and its characteristics.

3. Directive. In representative-ascertaining linguistic acts in which the model of a sentence with an active subject in combination with "modal verb + Indefinite Infinitive" is realized, the temporal modification of which is carried out by changing the form of a modal verb or changing it to a modal equivalent, in case of the absence of a corresponding temporal form" [2, c. 68].

"The epistemic meaning of modal verbs is realized in the linguistic acts of the sentence in combination with Continuous Indefinite, Passive Infinitive, as well as with the noun constructions " $b e+N / A d j$ ".

"Modal types of sentences that contain epistemic modal modifiers, namely modal words, modal constructions: Nominative + Infinitive, seem to, appear to, it is certain, modal phrases of type I think, are the main means of realizing representativesuggestive language acts that express uncertainty, certainty, epistemic possibility of the connection between the subject and its characteristics" [2, p. 69].
Also one of the means of expressing modality are modal words. "According to their meaning and depending on the expressed or subjective attitude to the facts of reality modal words can be classified into:

1. Words that express statements (of course, no doubt, surely, undoubtedly, evidently, naturally, obviously, really, actually, etc.).

2. Words expressing assumptions (perhaps, maybe, probably, possibly, supposedly).

3. Words that express subjective evaluation of the statement in terms of its desirability or undesirability (happy-unhappy, luckily-unluckily, fortunatelyunfortunately)" [8, p. 183].

Modality is also closely related to the predicative relation and "is a constructive factor of the sentence at the constructive-syntactic level" [7, p. 119]. Predicative modality is expressed by verb forms of the indicative and subjunctive mood, as well as sentence models with a compound modal predicate.

In English, modal verbs alongside other means of expressing modality form a semantic field of different modal meanings. In addition, since modal verbs are polysemantic, the same verb can refer to different semantic fields, for example:

\begin{tabular}{|c|c|}
\hline Probability & Necessity \\
\hline & must \\
\hline & have (to) \\
\hline be able (to) & be (to) \\
\hline must & need \\
\hline will & should \\
\hline be (to) & $\begin{array}{l}\text { ought (to) } \\
\text { shall }\end{array}$ \\
\hline
\end{tabular}

Each semantic field includes a wide range of shades of a certain modal meaning. For example, the modal meaning of necessity includes the assumption of possibility, the assumption bordering on certainty, probability, etc.

Modal verb must expresses:

1. Necessity, duty.

2. Assumptions, probability. In this case, this assumption borders on certainty. In this sense, the verb must is used in combination with the modal words most likely, most probably. In order to express assumptions of a negative nature, the verb must is used in combination with the infinitive of a verb of negative meaning or with the adverb never. In a number of stable combinations the modal meaning of the verb must is weakened.

Modal verb have (to) expresses:

1. Modal meaning of necessity due to certain circumstances. In this sense, it can be used in all types of sentences in combination with a non-perfect infinitive form.

2. Necessity as something planned earlier or stipulated by the agreement.

3. Necessity arising from an order, direction or instruction. 
4. Necessity as something determined by destiny.

Modal verb need expresses:

1. Necessity, which is realized in negative and interrogative sentences. In negative sentences, it takes on the meaning of a lack of necessity. In combination with the perfect form of need has the meaning of making an effort in vain due to the absence of the need for action.

2. In interrogative sentences the verb need acquires rhetorical meaning.

Modal verb should expresses:

1. Necessity as a recommendation, expressed in the form of subjective thought, often representing reproach or compassion.

2. Surprise or indignation (often in the form of a question).

Modal verb ought (to) expresses:

1. Moral duty, which is perceived naturally in certain conditions.

2. In combination with the perfect infinitive, ought (to) expresses the meaning of an unfulfilled duty, representing the meaning of pity or reproach.

3. Expression of the modality of the need in the political discourse

American politics tends to frequent use of the two forms of modality have to and must. Surprisingly, have to significantly outweighs all possible modalities of necessity. Apparently, it is due to the fact that politicians are reluctant to use must in their campaign speeches, as the must form has a more radical content. For example:

Clinton's 'House Divided' Springfield speech. This speech is full of constructions have to and must, such as:

- And sometimes we have to balance competing values like freedom and order, justice and security, these are complementary values of American life.

- And as President, he took pains to use the tools of government to create more economic opportunity for Americans at every level of society. So, too, must we fight inequality and create opportunity in our time - not just for some Americans, but for all.

John McCain concession speech is full of the modal verb must.

- This is an historic election, and I recognize the special significance it has for African-Americans and for the special pride that must be theirs tonight. I've always believed that America offers opportunities to all who have the industry and will to seize it.

Variants of modal necessity of such lexemes as should, need, ought to, necessary, expected etc. have a single fragmentary character.

It seems that speakers used have to in the most common topics discussed during the election campaign, which are related to tax issues, improving medical and judicial system, and resolving issues related to both illegal and legal immigration in the United States. The form have to is optimal for appealing to the voter in order to convince people of the need of completing the tasks, finding rational solution for the benefit of the people and the state. For example:

Donald Trump Speech in Miami contains constructions with modal verbs have to and must:

- We have to have a strong military. We have to take care of our vets. We have to take care of our vets.

- But it's been hurt very badly by Socialist Venezuela. And the next president of the United States must stand in solidarity with all people oppressed in our atmosphere. And we will stand with oppressed people.

McCain \& Obama The Third Presidential Debate; Obama \& Mitt Romney First U.S. Presidential Candidate Debate is accentuated by a frequent use of modal verbs have to:

- And we are now looking at a deficit of well over half a trillion dollars. So one of the things that I think we have to recognize is pursuing the same kinds of policies that we pursued over the last eight years is not going to bring down the deficit.

Trump-Clinton presidential debate filled with the use of a modal verb have to.

- And we're going to make America wealthy again, because if you don't do that, it just - it sounds harsh to say, but we have to build up the wealth of our nation.

According to the analysis of the speeches made by many candidates for the presidency in the United States, the following can be stated: the modal modifier have to $(41.2 \%)$ expresses the need due to moral obligation. The determining factor is the obligation to comply $(81 \%)$. This lexeme emphasizes the need, stipulated by a preliminary agreement.

The predominant number of uses have to is characterized by narrative sentences, often used in direct speech and imperative sentences.

In comparison with the lexeme must, which occurs in $18.1 \%$ of textual fragments and carries the meaning of moral obligation, it is worth noting its value of greater conclusiveness, the impossibility of non-compliance. Unlike the verbs should and ought to, which are characterized by the subjective views of the speaker, modal verb must conveys the need drawing on the objective reasons.

Must is a necessity caused by an order or authoritative opinion, the inner needs of the subject, as well as his physical and mental state, inner conviction. Thus, if the field of necessity contains 15 modal modifiers, then the core of this field is represented by polysemantic modal verbs have to and must. They most effectively convey the meaning of necessity and, accordingly, point out the congruence in their semantic structure. The distinctive feature of such a comparison is the frequency of their use depending on the type of discourse. 


\section{BIBLIOGRAPHY}

1. Беляева Е.И. Анализ системы средств выражения модальности вынужденности в методическом плане : методика обучения иноязычной устной речи. Воронеж : Воронеж. ун-тет, 1979. С. 8-12.

2. Беляева Е.И. Модальность в разных типах речевых актов : науч. докл. выш. шк. Филологические науки. 1989. № 3. С. 65-69.

3. Бирюлина Л.А. О лингвистических аспектах модальности : Сопряженность глагольных категорий. Калинин, 1990. С. 37-67.

4. Боженкова Н.А., Боженкова Р.К., Боженкова А.М. Современный политический дискурс: вербальная экземплификация тактико-стратегических предпочтений. Вестник РУДН. Серия: Русский и иностранные языки и методика их преподавания. Москва, 2017. T. 15. № 3. С. 255-284.

5. Виноградов В.В. О категории модальности и модальных словах в русском языке. Исследование по русской грамматике. Москва, 1975. С. 52-75.

6. Давиденко Л.Г. Некоторые общие вопросы языковой модальности : структура синтаксиса словосочетания и предложения в современном английском языке. / под ред. П.И. Шлейвис. Пятигорск, 1988. С. 110-111.

7. Ермолаева Л.С. К вопросу о соотношении модальности и предикативности. Филологические науки. 1963. № 4. С. 124-126.

8. Жигало В.Н., Иванова И.П., Иофик Л.Л. Современный английский язик : Теоретический курс граматики. Москва, 1966. С. 296.

9. Кривенко С.-В.О. Семантична парадоксальність політичного дискурсу (теоретико-методологічний аналіз) : дисертація на здобуття наукового ступеня кандидата політичних наук : 23.00.01. Львівський національний університет імені Івана Франка. Львів, 2016. $216 \mathrm{c}$.

10. Панфилов В.3. Роль модальности в конструировании предложения и суждения. Bonросы языкознания. 1977. № 4. С. 37-48.

11. Хлебникова И.Б. Еще раз о проблеме модальности в грамматике. Уч. записки МГПИИЯ им. М. Тореза. Москва, 1965. Т. 32. С. 354-363.

12. Холодович А.А. Очерки грамматики корейского языка. Москва : ИЛ, 1954. С. 253.

\section{REFERENCES}

1. Belyayeva, E.I. (1979). Analiz sistemy sredstv vyrazheniya modalnosti vynuzhdennosti $\mathrm{v}$ metodicheskom plane [Analysis of the system of means of expressing the modality of compul- sion in the methodological perspective]. Metodika obucheniya inoyazychnoy ustnoy rechi. Voronezh: Voronezh. un-tet, pp. 8-12.

2. Belyayeva, E.I. (1989). Modalnost v raznykh tipakh rechevykh aktov [Modality in different types of speech acts]. Filologicheskiye nauki, No. 3, pp. 65-69.

3. Biryulina, L.A. (1990). O lingvisticheskikh aspektakh modalnosti [On the linguistic aspects of modality]. Sopryazhennost glagolnykh kategoriy. Kalinin, pp. 37-67.

4. Bozhenkova, N.A., Bozhenkova, R.K., Bozhenkova, A.M. (2017). Sovremennyy politicheskiy diskurs: verbalnaya ekzemplifikatsiya taktiko-strategicheskikh predpochteniy [Modern political discourse: verbal exemplification of tactical and strategic preferences]. Vestnik RUDN. Seriya: Russkiy i inostrannyye yazyki i metodika $i k h$ prepodavaniya, Vol. 15, No. 3, pp. 255-284.

5. Vinogradov, V.V. (1975). O kategorii modalnosti i modalnykh slovakh v russkom yazyke [On the category of modality in the Russian language]. Issledovaniye po russkoy grammatike. Moscow, pp. 52-75.

6. Davidenko, L.G. (1988). Nekotoryye obshchiye voprosy yazykovoy modalnosti [Some general issues of linguistic modality]. Struktura sintaksisa slovosochetaniya $i$ predlozheniya $v$ sovremennom angliyskom yazyke / eds. Shleyvis P.I., Pyatigorsk, pp.110-111.

7. Ermolayeva, L.S. (1963). K voprosu o sootnoshenii modalnosti i predikativnosti [To the question of the relationship between modality and predicativity]. Filologicheskiye nauki, No. 4, pp. 124-126.

8. Zhigalo, V.N., Ivanova, I.P., Iofik, L.L. (1966). Sovremennyy angliyskiy yazyk [Modern English]. Moscow, pp. 296.

9. Krivenko, S.-V.O. (2016). Semantichna paradoksalnist politichnogo diskursu (teoretiko-metodologichniy analiz) [Semantic paradoxical political discourse (theoretical and methodological analysis)]. PhD Thesis, Lviv, Ivan Franko National University of Lviv.

10. Panfilov, V.Z. (1977). Rol modalnosti v konstruirovanii predlozheniya i suzhdeniya [The role of modality in the construction of sentences and judgments]. Voprosy yazykoznaniya. No. 4. Pp. 37-48.

11. Khlebnikova, I.B. (1965). Eshche raz o probleme modalnosti $\mathrm{v}$ grammatike [Once again on the problem of modality in grammar]. Uch. zapiski MGPIIYa im. M. Toreza, Vol. 32, pp. 354-363.

12. Kholodovich, A.A. (1954). Ocherki grammatiki koreyskogo yazyka. [Essays on the grammar of the Korean language]. Moscow: IL, p. 253. 